\title{
The Role of Teacher Morale and Motivation on Students' Science and Math Achievement: Findings from Singapore, Japan, Finland and Turkey
}

\author{
İkay Abazaoğlu ${ }^{1, *}$, Serdar Aztekin ${ }^{2}$ \\ ${ }^{1}$ Science and Art Center, Turkey \\ ${ }^{2}$ Faculty of Education, Gazi University, Turkey
}

Copyright $\bigcirc 2016$ by authors, all rights reserved. Authors agree that this article remains permanently open access under the terms of the Creative Commons Attribution License 4.0 International License

\begin{abstract}
Teacher motivation is one of the factors that affect the realization of the teaching objectives, motivation and academic achievement of student. This study aimed to answer to the question "How is the relation between the students' academic (sciences and mathematics) achievement and teachers' morale/motivation in Singapore, Japan, Finland and Turkey?" by using PISA 2012 data and TIMSS 2011 data. The researchers used descriptive statistics and hierarchical linear modeling (HLM) in order to study the effects of the morale and motivation qualities of the sciences and mathematics teachers on students' academic achievement. Moreover, comparisons were made in this field according to the obtained results. The results showed that the teacher factor was more effective in countries with different income balance while the teacher morale and motivation generally has a positive effect according to both PISA and TIMSS data. For example in Turkey and Singapore, teacher motivation has more effect on the academic achievement of the students. It was found that school principals express a high morale and motivation for their teachers in high performer countries. Students' achievements were mostly effected in Turkey by teacher morale. In the light of the findings, recommendations were made to increase the sciences and mathematics achievements of students.
\end{abstract}

Keywords PISA, TIMSS, Teacher Morale, Science Literacy, Math Literacy, Motivation

\section{Introduction}

Focusing on teachers, one of the basic components of the education system is an effective approach for the researchers and policy makers who attempt to find ways to improve education. Conforming the existing perception, the previous studies underline the fact the student achievement is mainly based on their teachers. In this respect, it has been argued that the teachers are the most basic resource of the system by also emphasizing the fact the teacher salaries are the greatest share of the primary education budget [26].

Professional motivation refers to a psychological process affecting the behaviors of individuals for realizing goals and tasks in a workplace [4]. In this respect, teacher motivation is one of the factors that affect the realization of the teaching objectives, motivation and academic achievement of student. This has been underlined in many researches in the literature that reveal the teacher qualities are related with the student learning and achievement $[2,4,6,13,15,23]$. These studies mainly found a positive relation between the morale of teachers and student achievement and underlined the positive effect of the teacher morale on the attitude and learning desire of students.

In the literature, there are many studies focusing on the job satisfaction, motivation and morale of the teachers of mathematics and sciences. These studies mainly focused on the factors affecting the job satisfaction and motivations of teachers. Cemaloğlu [5] stated that the teacher motivation is affected by the frequent and long lasting face to face relations of teachers with students, parents, managers and staff and by the work in over-crowded classrooms. Balc1 [3] ranked the most important motivating factors for teachers as follows: (1) "peace and good relations at the working environment": (2) "moral support and incentives", (3) "material support and incentives" and (4) "having a good dialogue with students and parents". Other motivating factors are stated as "loving teaching, students, job, people and serving to people", "to see the student achievement and outcome of education", "loving to be in constant action" and "being trained for teaching with respect to professional knowledge and formation". Balc1 [3] argues that the teaching profession is actually done based on the importance assigned to the act of teaching. This importance has parallels with the appreciation of the teaching profession by the society. In the study the ratio of the teachers who think that the teaching profession is appreciated by the society was found to be $45 \%$. 
Another remarkable finding of the study is related to the professional satisfaction of the teachers in Turkey. $27 \%$ of the teachers stated that they would quit the teaching profession at the first opportunity.

Esteve [8] provided a different point of view to the teacher motivation and studied the factors revealing the motivation differences among teachers in two groups. The first group of factors is the negative conditions that directly affect the teacher in the classroom and thus cause tension like tools, materials, negative working conditions, student violence on teachers, increasing teacher expectations and tiredness of teacher. Second group of factors are the environmental factors. All of these factors indirectly affect the academic achievement of the students.

According to the PISA 2012 results, one of the factors with positive effect on the mathematics achievement of students is found to be the levels of "teachers" morale" [2]. The study emphasized that there was a statistically significant relation between the teachers' morale and student achievement. When the effect of the factors expressing the school level material and human resources is compared, it was observed that the teachers' morale factor and the school education resources quality factor were the most effective two factors on the mathematics achievement of the students.

In the literature, the factors affecting the academic achievements of students are generally listed as follows:

- Teachers

- Teachers' motivation

- Their morale at school

- Enthusiastic works

- Being proud of being at school

- Appreciation of academic achievement

- Socio-economic infrastructure

- School environment

- Family structure

- Friendship environment and similar factors.

\subsection{PISA and TIMSS Applications}

Programmer for International Student Assessment - PISA and Trends in International Mathematics and Sciences Study - TIMSS are the international survey researches with the largest samples carrying out measurements and evaluations in the fields of mathematics and sciences. Both use surveys to measure the qualities of teachers and students.

PISA focuses on the ability of young people to use their knowledge and skills to overcome the problems they would face in daily life. The PISA tests and surveys conducted every three years by OECD (The Organization for Economic Co-operation and Development) focuses each year on one of the three subjects (reading skills, mathematics literacy and sciences literacy). The PISA test intends to evaluate the qualifications, interests and attitudes of the students in the age group of 15 in different areas, to determine the strong and improvable aspect of the education system and to determine the policies to increase quality and achievement in education [18]. PISA application evaluates whether the individuals acquire knowledge and skills that are necessary for the individuals to take their place in the modern society [18]. The PISA tests include student achievement test, student survey and school survey. The information on the teacher qualities are usually collected by the school surveys completed by the school principals. Items on the teacher morale and motivation are also included in this survey.

TIMSS is a survey research carried out by IEA (International Association for the Evaluation of Educational Achievement) to evaluate the 4th year and 8th year students in the participating countries. Different from PISA, it is repeated every four years. If analyzed properly, it provides data that allow evaluation and international comparisons on different education systems. Like PISA, TIMSS is helpful in the collection of detailed information on school environments and resources and in the determination of factors to bring success in education [24]. TIMSS applications evaluate the qualifications of teachers and students with the student achievement test, student survey, teacher survey and school survey.

The studies conducted in Turkey on the teacher qualities are usually based on the views of principals, teachers, students or prospective teachers. The studies that examine in detail the effects of teacher motivation on student achievement are very limited [1,12,20,23]. The objective of this study is to evaluate the TIMSS 2011 sciences and mathematics achievements and PISA 2012 results of mathematics literacy and sciences literacy according to the variant of teachers' morale for four countries (Singapore, Japan, Finland and Turkey) by using the broad database provided by the TIMSS and PISA applications. The researchers compared the results of Singapore, Japan, Finland and Turkey indicating their performance in TIMSS 2011 and PISA 2012. This study is the part of a broader study on the teacher qualities of some countries according to TIMSS 2011 and PISA 2012 and it is dedicated on the teachers' morale and motivations. The concepts of morale and motivation used in this study refer to the driving force of teachers to fulfill their tasks [25].

The study sought answer to the question "How is the relation between the sciences and mathematics achievement of the students and teachers' motivation in Singapore, Japan, Finland and Turkey?" and attempted to determine the change of the effect of the indices of morale and motivations of the sciences teachers and mathematics teachers on the academic achievement of students in the sciences and mathematics lessons. Moreover, comparisons were made in this field according to the obtained results. In the light of the findings, recommendations were made to increase the sciences and mathematics achievements of students. In this context, it is believed that studying the effect of morale and motivations of teachers in these countries on the academic achievement of students will contribute to the determination of the qualities of the studied group and planning of the teachers' qualifications and competencies in teacher training programmers. 


\section{Method}

\subsection{Model of the Research}

This study is a survey model and uses the descriptive statistics and hierarchical linear modeling (HLM) in order to study the effects of the morale and motivation qualities of the sciences and mathematics teachers on the academic achievement of students in sciences and mathematics. The researchers also made comparisons on this subject according to the results obtained from the PISA 2012 and TIMSS 2011 database. The researchers used descriptive statistics to present data obtained from PISA and TIMSS. Then they constructed hierarchical models to determine the effects of some teachers' qualities on students' science and math achievement by using TIMSS and PISA database. The models constructed by the researchers for this study are given in the HLM data analysis section.

\subsection{The Sample of the Study}

For TIMSS 2011, the population of the study consists of the grade 8 students, sciences teachers and mathematics teachers working in Singapore, Japan, Finland and Turkey. For PISA 2012, the population of the study consists of 15-year-old students and the school principals in these countries. The reason to include Singapore, Japan and Finland in the study is that these countries have high performance in both PISA and TIMSS tests. In this way, it is attempted to evaluate the teachers' morale and the effect on student achievement of the good performance countries and Turkey which has a rather low performance compared to the other OECD countries. The number of teachers, students and schools participated in the TIMSS 2011 and PISA 2012 applications in the four countries were given in the Table 1.

\subsection{Data Gathering Tools}

This study considered the effects of the teachers' motivation (morale) items and indices on the academic achievements of the 8th grade students participated in TIMSS 2011 and the 15 years old students participated in PISA 2012 in Singapore, Japan, Finland and Turkey. In order to make comparisons between the results, the researchers used both databases; PISA 2012 database and TIMSS 2011 database.

Data on the PISA 2012 test was obtained from the items about teacher morale in the PISA 2012 school questionnaire responded by the school principals. It was obtained from the PISA 2012 database website of OECD. The school principals were asked how they agree with each of the four statements on the following (Figure 1).

The researchers used the index of Teacher Morale (TCMORALE) to analyze the effect of teacher morale and motivation on academic achievement. This index was obtained from these four statements in the school questionnaire.

\section{Think about the teachers in your school. How much do you} agree with the following statements?

(Please check one box in each row.)

$$
\begin{gathered}
\text { Strongly } \\
\text { agree }
\end{gathered} \quad \text { Agree Disagree } \begin{gathered}
\text { Strongly } \\
\text { disagree }
\end{gathered}
$$

a) The morale of teachers in this school is high.

b) Teachers work with enthusiasm.

c) Teachers take pride in this school.

d) Teachers value academic achievement.

Figure 1. Items in the PISA 2012 School Questionnaire

Table 1. Number of Teachers, Students and Schools who are the sample of the study

\begin{tabular}{|cccccc|}
\hline & Sciences teacher & $\begin{array}{c}\text { TIMSS 2011 } \\
\text { Mathematics } \\
\text { teacher }\end{array}$ & $\begin{array}{c}\text { Number of } \\
\text { Students }\end{array}$ & Schools & $\begin{array}{c}\text { Pumber of } \\
\text { Students }\end{array}$ \\
Singapore & 165 & 165 & 5.927 & 176 & 5.546 \\
Japan & 138 & 138 & 4.414 & 200 & 6.351 \\
Finland & 145 & 145 & 4.266 & 313 & 8.829 \\
Turkey & 239 & 239 & 6.978 & 170 & 4.848 \\
\hline
\end{tabular}


The TIMSS 2011 data was obtained from the Data Process Centre (DPC) (rms.iea-dpc.org) of the International Association for the Evaluation of Educational Achievement (IEA). The question "how much do you agree with the following statement?" in the TIMSS 2011 Teacher Questionnaire intending to determine the morale level and motivation of the teachers was directly addressed to teachers. The researchers determined three items related with teacher morale and motivation responded by the science and math teachers (Figure 2).

\section{How much do you agree with the following statements?}

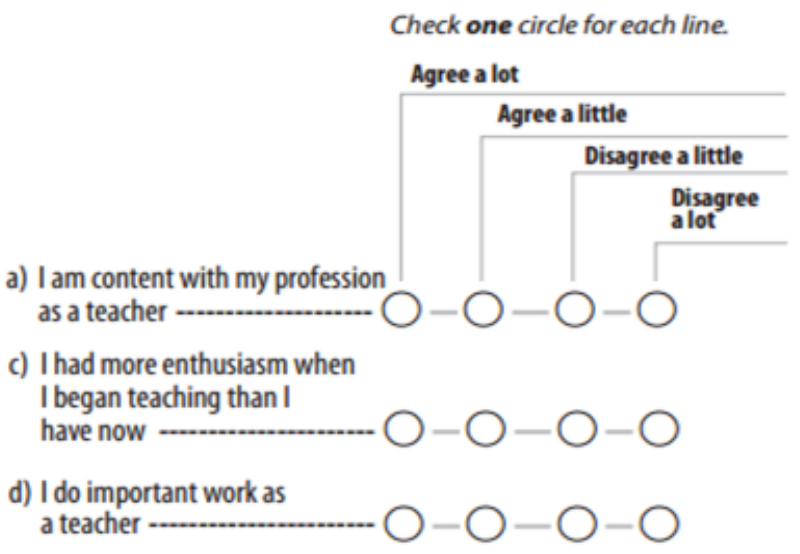

Figure 2. Items in the TIMSS 2011 Teacher Questionnaire

\subsection{HLM Analysis of Data}

Since the data set used in TIMSS 2011 are nested, that is the students are clustered in the classroom and classrooms are clustered in the school, the Hierarchical Linear Modelling (HLM) method was used in the study [22]. A two-stage HLM was created to examine the effect of the teacher morale qualities on the sciences and mathematics achievements of students for each country. For the analysis, the researchers used the HLM 7.00 computer software developed by Raudenbush, Bryk and Congdon. HLM is used when the predictor variables are in different hierarchical levels. It is a form of ordinary least squares (OLS) regression which is used for analyzing variance in the outcome variables [27]. At the beginning, the researchers established a "null" model to analyze the variance that occurs within schools and the variance that occurs between schools (or teachers). They also obtained estimates of HLM means and standard deviations.

To analyze the TIMSS 2011 data, the researchers established a two level HLM model for each country with students nested within classrooms at level 1, classrooms nested within schools at level 2. Interclass Correlation Coefficient (ICC) was determined and the regression coefficients were calculated in an unbiased manner. In the model, the dependent variable was students' mathematics and science scores respectively. There was not any student level (level-1) variable in the model. At the school level (level-2) indicators were selected which are related with teachers morale and motivation; doing important work, being more enthusiastic at the beginning, satisfaction with being a teacher. Two level null and full models used for the analysis of TIMSS data are on the following:

Null model:

Level-1: $Y_{\mathrm{ij}}\left(\right.$ ACHIEVEMENT $\left._{\mathrm{ij}}\right)=\beta_{0 \mathrm{j}}+\mathrm{r}_{\mathrm{ij}}$ Level- $2: \beta_{0 \mathrm{j}}=\gamma_{00}+\mathrm{u}_{0 \mathrm{j}}$

Combined Model: $\mathrm{Y}_{\mathrm{ij}}\left(\right.$ ACHIEVEMENT $\left._{\mathrm{ij}}\right)=\gamma_{00}+\mathrm{u}_{0 \mathrm{j}}+\mathrm{r}_{\mathrm{ij}}$

In this model,

$Y_{\mathrm{ij}}$ : Science achievement score measured for $i$ th student nested within $j$ th classroom,

$\beta_{0 j}$ : mean of the $j$ th classroom,

$\mathrm{r}_{\mathrm{ij}}$ : error associated with the $i$ th student nested within $j$ th classroom,

$\gamma_{00}$ : overall mean of the classrooms,

$\mathrm{u}_{0 \mathrm{j}}$ : error associated with the $j$ th classroom,

Full model:

Level-1:(ACHIEVEMENT $i \mathrm{ij})=\beta_{0 \mathrm{j}}+\mathrm{r}_{\mathrm{ij}}$ Level-2: $\beta_{0 \mathrm{j}}=\gamma_{00}+\gamma_{01} *\left(\right.$ SATISFACTION $\left._{\mathrm{j}}\right)+$ $\gamma_{02} *\left(\right.$ ENTHUSIASM $\left._{\mathrm{j}}\right)+\gamma_{03} *\left(\right.$ GIVINGIMPORTANCE $\left._{\mathrm{j}}\right)$ $+\mathrm{u}_{0 \mathrm{j}}$

Combined Model:

ACHIEVEMENT $_{\mathrm{ij}}=\gamma_{00}+\gamma_{01}$ $_{\text {SATISFACTION }}+$ $\gamma_{02} *$ ENTHUSIASM $_{\mathrm{j}}+\gamma_{03} *$ GIVINGIMPORTANCE $_{\mathrm{j}}$ $+\mathrm{u}_{0 \mathrm{j}}+\mathrm{r}_{\mathrm{ij}}$

In this model,

$\gamma_{00}$ : intercept adjusted for each classroom $\gamma_{01}, \gamma_{02}$ and $\gamma_{03}$ : regression coefficients of selected indicators (SATISFACTION, ENTHUSIASM and GIVING IMPORTANCE)

$\mathrm{u}_{0 \mathrm{j}}$ : errors associated with the classroom level variables

To analyze the PISA 2012 data, again the researchers established a two level HLM model for each country with students nested within schools at level 1, schools nested within the country at level 2 . The dependent variables were science and mathematics literacy scores. There was not any student level (level-1) variable in the model. At the school level (level-2) the index of Teacher Morale was selected to effect of teachers' morale and motivation. Two level null and full models used for the analysis of PISA 2012 data are on the following:

Null model:

Level-1: $Y_{\mathrm{ij}}\left(\right.$ ACHIEVEMENT $\left._{\mathrm{ij}}\right)=\beta_{0 \mathrm{j}}+\mathrm{r}_{\mathrm{ij}}$

Level-2: $\beta_{0 \mathrm{j}}=\gamma_{00}+\mathrm{u}_{0 \mathrm{j}}$

Combined Model:

$$
\mathrm{Y}_{\mathrm{ij}}\left(\mathrm{ACHIEVEMENT}_{\mathrm{ij}}\right)=\gamma_{00}+\mathrm{u}_{0 \mathrm{j}}+\mathrm{r}_{\mathrm{ij}}
$$

In this model,

$Y_{i j}$ : Achievement score measured for $i$ th student nested within $j$ th school,

$\beta_{0 j}$ : mean of the $j$ th school,

$r_{i j}$ : error associated with the $i$ th student nested within $j$ th school,

$\gamma_{00}$ : overall mean of the schools, 
$u_{0 j}$ : error associated with the $j$ th school.

Full model:

Level-1: $\left(\right.$ ACHIEVEMENT $\left.{ }_{\mathrm{ij}}\right)=\beta_{0 \mathrm{j}}+\mathrm{r}_{\mathrm{ij}}$

Level-2: $\quad \beta_{0 \mathrm{j}}=\gamma_{00}+\gamma_{01} *($ TCMORALEj $)+\mathrm{u}_{0 \mathrm{j}}$

Combined Model:

ACHIEVEMENT $_{\mathrm{ij}}=\gamma_{00}+\gamma_{01} *$ TCMORALE $_{\mathrm{j}}+\mathrm{u}_{0 \mathrm{j}}+\mathrm{r}_{\mathrm{ij}}$

In this model,

$\gamma_{00}$ : intercept adjusted for each school,

$r_{i j}$ : error associated with the $i$ th student nested within

$j$ th school,

$\beta_{0 j}$ : mean of the $j$ th School,

$\gamma_{01}:$ regression coefficient of (TCMORALE)

$u_{0 j}$ : errors associated with the school level variables

\section{Findings}

The findings section on the motivations of teachers was divided into two under the headings of "TIMSS 2011 Results" and "PISA 2012 Results".

\subsection{TIMSS 2011 Results}

Table 2 was formed by calculating the separate in-class (between students) and interclass (between teachers) correlation coefficients of the countries included in the study with the HLM analysis method as well as the academic achievement average scores of students in the TIMSS 2011 test. The variation at all levels is significant $(\mathrm{p}<.05)$.

Table 2. TIMSS 2011, Sciences Achievement Scores of Students and HLM Analysis Results

\begin{tabular}{|c|c|c|c|}
\hline TIMSS & $\begin{array}{c}\text { Students' Sciences } \\
\text { Achievement } \\
\text { Score Average }\end{array}$ & $\begin{array}{c}\text { Variance } \\
\text { between } \\
\text { teachers (\%) }\end{array}$ & $\begin{array}{c}\text { Variance } \\
\text { between } \\
\text { students (\%) }\end{array}$ \\
\hline Singapore & 590 & 42 & 58 \\
\hline Japan & 558 & 8 & 92 \\
\hline Finland & 552 & 12 & 88 \\
\hline Turkey & 483 & 29 & 71 \\
\hline
\end{tabular}

In Table 2 it is seen that the highest explanatory rate in the correlation calculations according to the interclass/interteacher variance values of the countries within the study is in the Singapore data with $42 \%$ and the least explanatory rate of the same is in the Japan data with $8 \% .58 \%$ of the sciences achievement scores of students in Singapore is explained by the in-class differences. In Finland, $88 \%$ of the sciences achievement scores of students is explained by the in-class differences and $12 \%$ of the same is explained by the interclass differences. Turkey is more like Singapore according to these results. For science achievement, approximately $29 \%$ of the variance occurs between teachers (classrooms) in Turkey.
Table 3 was formed by the calculations conducted according to the mathematics achievement scores. The separate in-class (between students) and interclass (between teachers) correlation coefficients of the countries included in the study and the mathematics achievement average scores of students are on the following:

Table 3. TIMSS 2011, Mathematics Achievement Scores of Students and HLM Analysis Results

\begin{tabular}{|c|c|c|c|}
\hline TIMSS & $\begin{array}{c}\text { Students' } \\
\text { Mathematics } \\
\text { Achievement } \\
\text { Score Average }\end{array}$ & $\begin{array}{c}\text { Variance } \\
\text { between } \\
\text { teachers (\%) }\end{array}$ & $\begin{array}{c}\text { Variance } \\
\text { between } \\
\text { students (\%) }\end{array}$ \\
\hline Singapore & 611 & 41 & 59 \\
\hline Japan & 570 & 13 & 87 \\
\hline Finland & 514 & 13 & 87 \\
\hline Turkey & 452 & 32 & 68 \\
\hline
\end{tabular}

According to the results in Table 3 , there is not much difference between correlation calculations related to science and mathematics achievement. Again, the highest explanatory rate in the correlation calculations according to the interclass/interteacher variance values of the countries within the study is in the Singapore data with $41 \%$ and the least explanatory rate of the same is in the data of Japan and Finland $13 \%$. 59\% of the mathematics achievement scores of students in Singapore is explained by the in-class differences. In Turkey, $68 \%$ of the mathematics achievement scores of students is explained by the in-class differences and $32 \%$ of the same is explained by the interclass differences.

The followings are the HLM analysis results according to the responses to the items related with teachers' morale participated in TIMSS 2011. Three main indicators about teachers' morale are "being satisfied or contented with profession", "having more enthusiasm at the beginning" and "giving importance to the profession". Graph 1 includes the results related with the item "I am content with my profession as a teacher" in the TIMSS teacher questionnaire.

According to the HLM analysis results in Graph 1, the satisfaction of the teachers participated in the TIMSS 2011 increase the academic achievement scores of students. In mathematics, the highest increase is in Singapore. One unit increase in the satisfaction level of teachers in Singapore may cause an increase of around 20 points in mathematics regarding the mathematics achievement average scores of students. The expected increase in mathematics achievement scores is also higher in Turkey than other countries; Japan and Finland. On the other hand all of the results in mathematics are statistically significant. It is seen that the highest increase was in Turkey in science (19 points) and there are two statistically significant results from Singapore and Turkey. 


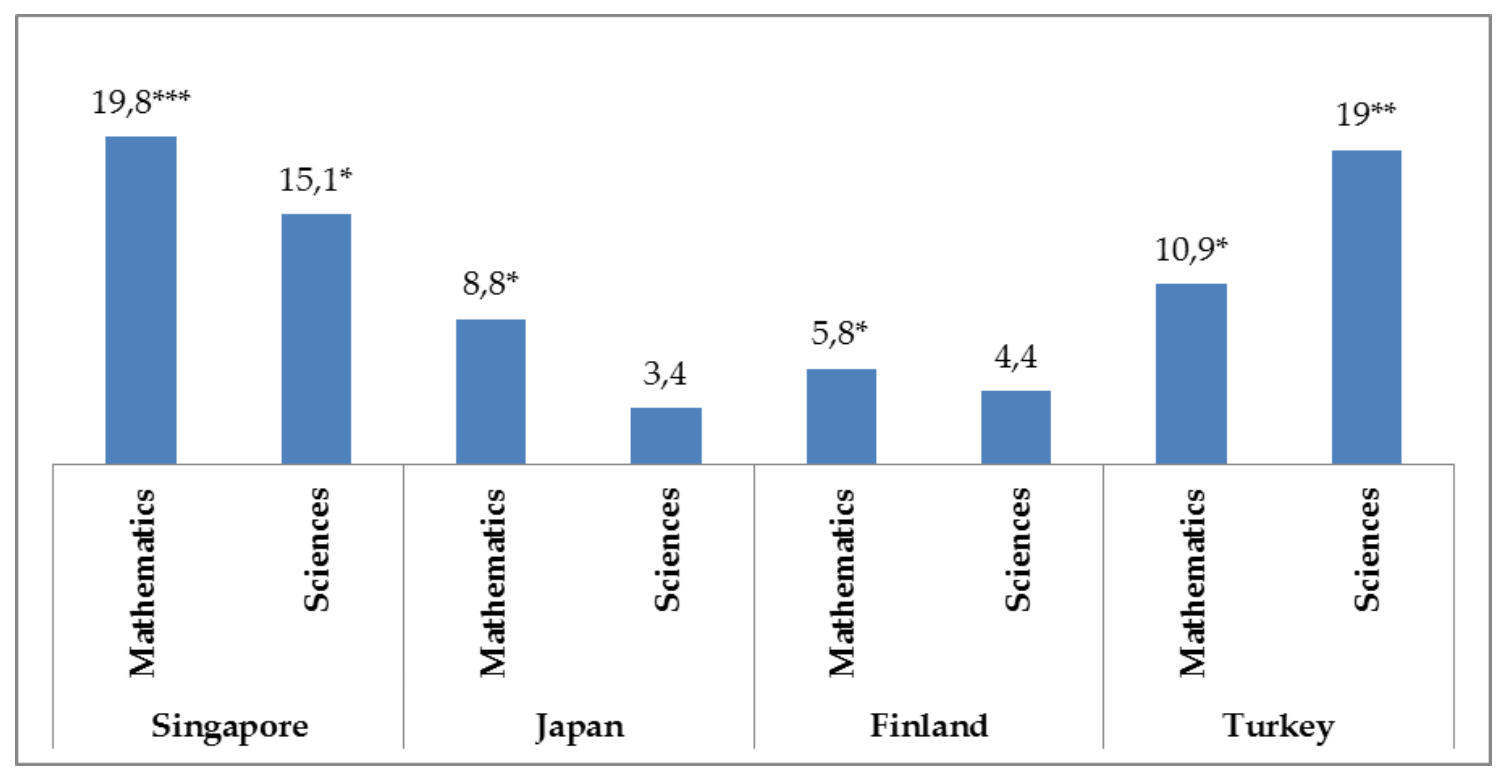

Note: ${ }^{*} \mathrm{p}<0.1 ; * * \mathrm{p}<0.01 ; * * * \mathrm{p}<0.001$

Graph 1. HLM results of the indicator "being satisfied with profession"

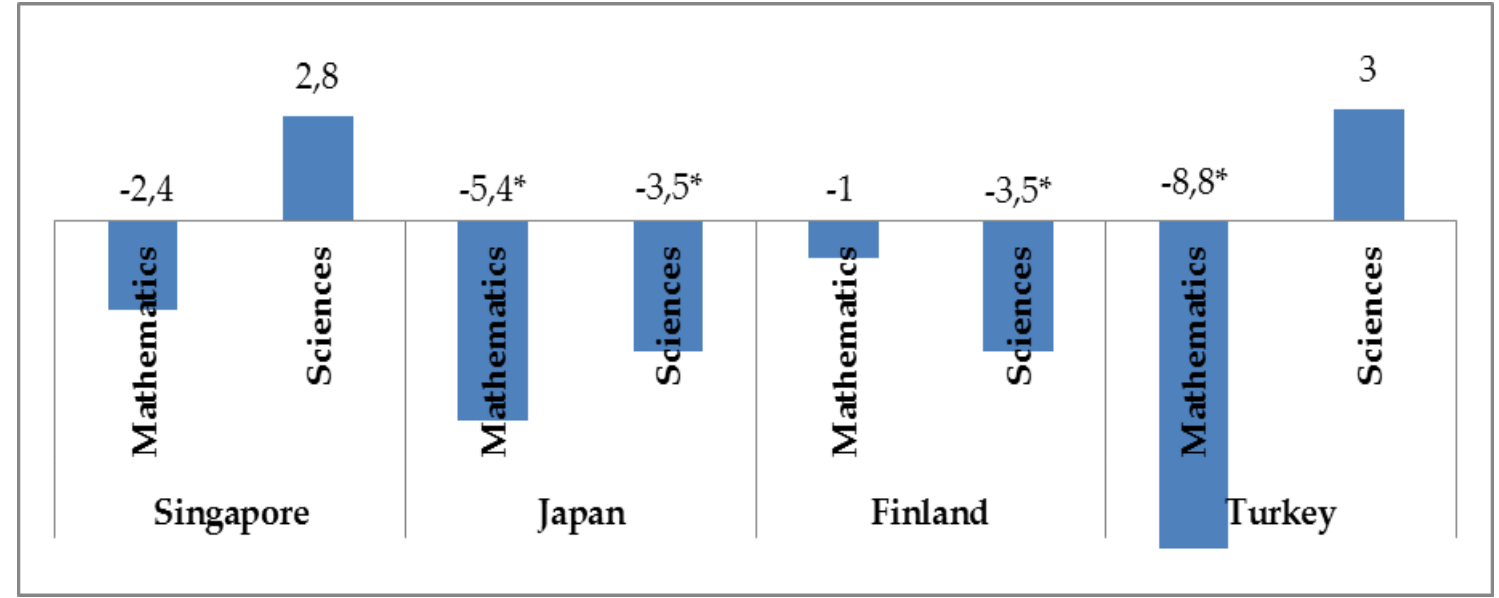

Note: $* \mathrm{p}<0.1 ; * * \mathrm{p}<0.01 ; * * * \mathrm{p}<0.001$

Graph 2. HLM results of the indicator "having more enthusiasm at the beginning"

Graph 2 includes the results related with the item "I had more enthusiasm when I began teaching than I have now" in the TIMSS teacher questionnaire.

According to the HLM analysis results in Graph 2, the enthusiasm level of the teachers participated in the TIMSS 2011 may cause changes in the academic achievement scores of students. According to the mathematics results the decrease of enthusiasm effects negatively in all countries. On the other hand there are positive effects in Singapore and Turkey, but they are not statistically significant. The expected decrease in the mathematics achievement scores in Turkey is nearly 9 points.

Graph 3 includes the results related with the item "I do important work as a teacher" in the TIMSS teacher questionnaire. 


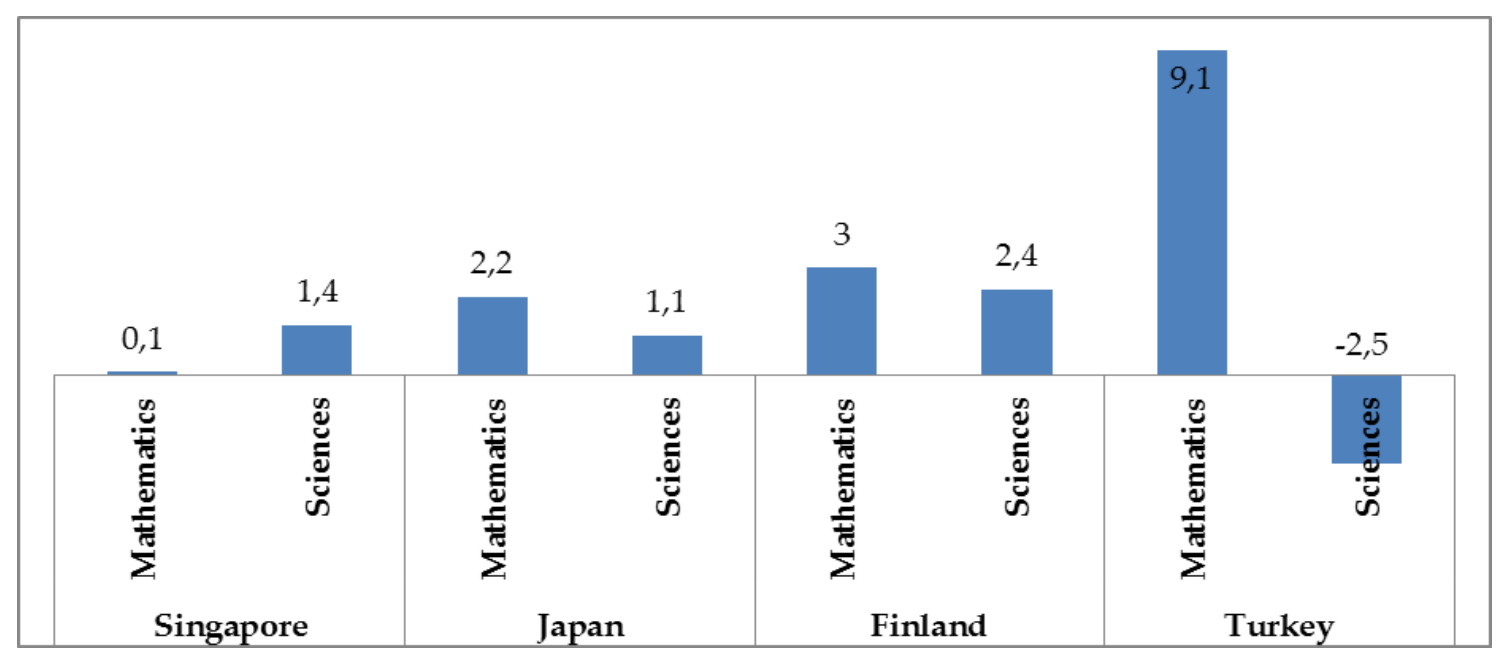

Note: ${ }^{*} \mathrm{p}<0.1 ; * * \mathrm{p}<0.01 ; * * * \mathrm{p}<0.001$

Graph 3. HLM results of the indicator "giving importance to the profession"

Although the results are not statistically significant, it is seen that "giving importance to the teacher profession" may increase the academic achievement scores of students. Only in Turkey, there is a negative effect in the sciences achievement scores of students. In mathematics, the expected increase in the average achievement scores is about 9 points in Turkey and there is almost no change in Singapore.

\subsection{PISA 2012 Results}

The results obtained from the school principals' reports about teachers' morale are presented in this section. Graph 4-7 and Tables 4-7 include the responses and percentage distributions given by the school principals to the variables under the question "How much do you agree with the following statements on the teachers at your school?" included in the PISA School Questionnaire.

Graph 4 includes the percentage distribution of the school principals' responses to the item "the morale of teachers in this school is high" included in the PISA 2012 school questionnaire.

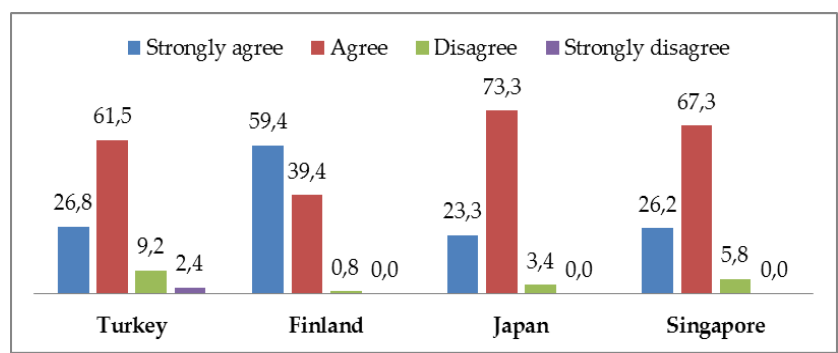

Graph 4. PISA 2012, "The morale of teachers in this school is high."

As seen in Graph 4, the principals of the schools reported a high morale rate about teachers according to the PISA 2012 data. In the countries except Turkey, more than $90 \%$ of the students in the schools whose principals strongly agree or agree that teachers have high morale rate. In Turkey, this rate is less than $90 \%$.
Table 4 includes the achievement scores according to the responses to the item "The morale of teachers in this school is high" included in the PISA 2012 school questionnaire.

Table 4. Scores according to the responses to the item "The morale of teachers in this school is high."

\begin{tabular}{|c|c|c|c|c|c|}
\hline \multirow[b]{2}{*}{ Country } & \multirow[b]{2}{*}{ Category } & \multicolumn{2}{|c|}{ Mathematics } & \multicolumn{2}{|c|}{ Science } \\
\hline & & Mean & (SE) & Mean & (SE) \\
\hline \multirow{4}{*}{ Turkey } & Strongly agree & 473 & $(12,71)$ & 481 & $(10,06)$ \\
\hline & Agree & 442 & $(5,11)$ & 460 & $(4,42)$ \\
\hline & Disagree & 414 & $(14,93)$ & 429 & $(10,78)$ \\
\hline & $\begin{array}{l}\text { Strongly } \\
\text { disagree }\end{array}$ & 447 & $(37,66)$ & 481 & $(32,30)$ \\
\hline \multirow{4}{*}{ Finland } & Strongly agree & 518 & $(2,92)$ & 546 & $(2,81)$ \\
\hline & Agree & 520 & $(2,41)$ & 545 & $(3,35)$ \\
\hline & Disagree & 500 & $(28,54)$ & 529 & $(30,12)$ \\
\hline & $\begin{array}{l}\text { Strongly } \\
\text { disagree }\end{array}$ & $\mathrm{a}$ & (a) & $\mathrm{a}$ & (a) \\
\hline \multirow{4}{*}{ Japan } & Strongly agree & 554 & $(11,63)$ & 562 & $(10,34)$ \\
\hline & Agree & 532 & $(4,46)$ & 543 & $(4,54)$ \\
\hline & Disagree & 507 & $(17,57)$ & 529 & $(19,75)$ \\
\hline & $\begin{array}{l}\text { Strongly } \\
\text { disagree }\end{array}$ & $\mathrm{a}$ & (a) & $\mathrm{a}$ & (a) \\
\hline \multirow{4}{*}{ Singapore } & Strongly agree & 599 & $(2,58)$ & 577 & $(2,68)$ \\
\hline & Agree & 570 & $(1,54)$ & 548 & $(1,68)$ \\
\hline & Disagree & 516 & $(4,40)$ & 496 & $(4,46)$ \\
\hline & $\begin{array}{l}\text { Strongly } \\
\text { disagree }\end{array}$ & $\mathrm{a}$ & (a) & $\mathrm{a}$ & (a) \\
\hline
\end{tabular}

a: The category does not apply in the country concerned, Data therefore missing

Resource: PISA 2012 Database 
As seen in Table 4, high morale of teachers in their schools increases the academic achievement average scores of students according to the PISA 2012 results. The academic achievement average score of the students in the schools in Singapore whose principals responded with "strongly agree" to the item "the morale of teachers in this school is high" is 83 points higher in mathematics and 81 points higher in sciences than the academic achievement average scores of the students of the principals who responded with "strongly disagree". The least increase was in Finland. The academic achievement average scores of the students in Finland are 18 points higher in mathematics and 17 points higher in sciences.

Graph 5 includes the percentage distribution of the school principals' responses to the item "Teachers work with enthusiasm." included in the PISA 2012 school questionnaire.

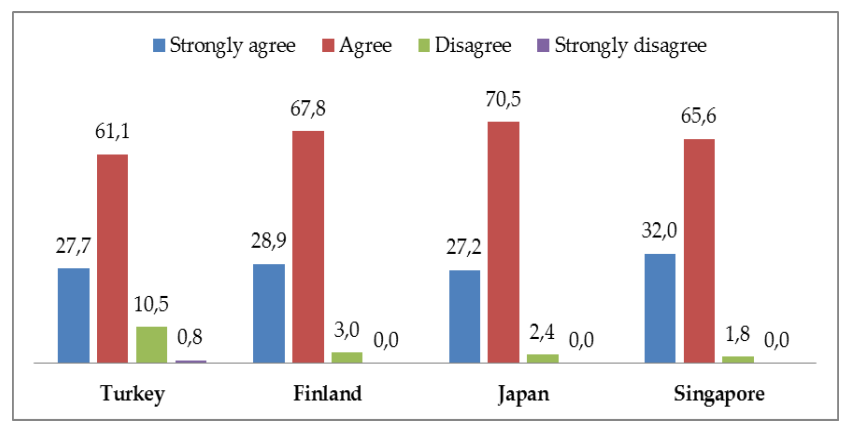

Graph 5. PISA 2012 "Teachers work with enthusiasm"

The principals of the schools also reported a high enthusiasm rate about teachers according to the PISA 2012 data. Less than $90 \%$ of the students in the schools in Turkey whose principals strongly agree or agree that teachers work with enthusiasm, while in other countries this rate is more than $90 \%$ (Graph 5).

Table 5 includes the achievement scores according to the responses to the item "Teachers work with enthusiasm." included in the PISA 2012 school questionnaire.

As seen in Table 5, enthusiastic work of teachers increases the academic achievement average scores of students according to the PISA 2012 results. The academic achievement average score of the students of the principals in Japan who responded with "strongly agree" to the item "Teachers work with enthusiasm" is 34 points higher in mathematics and 22 points higher in sciences than the academic achievement average score of the students of the principals who responded with "strongly disagree". The least increase was in Finland. The academic achievement average score of the students in Finland is 9 points higher in mathematics and 3 points higher in sciences.
Table 5. Scores according to the responses to the item "Teachers work with enthusiasm."

\begin{tabular}{|c|c|c|c|c|c|}
\hline \multirow[b]{2}{*}{ Country } & \multirow[b]{2}{*}{ Category } & \multicolumn{2}{|c|}{ Mathematics } & \multicolumn{2}{|c|}{ Science } \\
\hline & & Mean & (SE) & Mean & (SE) \\
\hline \multirow{4}{*}{ Turkey } & Strongly agree & 462 & $(14,55)$ & 475 & $(12,22)$ \\
\hline & Agree & 441 & $(5,72)$ & 458 & $(4,85)$ \\
\hline & Disagree & 444 & $(16,67)$ & 459 & $(14,08)$ \\
\hline & $\begin{array}{l}\text { Strongly } \\
\text { disagree }\end{array}$ & 569 & $(5,03)$ & 585 & $(4,27)$ \\
\hline \multirow{4}{*}{ Finland } & Strongly agree & 521 & $(4,12)$ & 548 & $(3,53)$ \\
\hline & Agree & 518 & $(2,09)$ & 544 & $(2,63)$ \\
\hline & Disagree & 512 & $(4,68)$ & 545 & $(6,84)$ \\
\hline & $\begin{array}{l}\text { Strongly } \\
\text { disagree }\end{array}$ & $\mathrm{a}$ & (a) & $\mathrm{a}$ & (a) \\
\hline \multirow{4}{*}{ Japan } & Strongly agree & 550 & $(10,34)$ & 557 & $(9,37)$ \\
\hline & Agree & 532 & $(4,81)$ & 543 & $(4,79)$ \\
\hline & Disagree & 516 & $(24,49)$ & 535 & $(25,43)$ \\
\hline & $\begin{array}{l}\text { Strongly } \\
\text { disagree }\end{array}$ & $\mathrm{a}$ & (a) & $\mathrm{a}$ & (a) \\
\hline \multirow{4}{*}{ Singapore } & Strongly agree & 595 & $(2,57)$ & 572 & $(2,73)$ \\
\hline & Agree & 565 & $(1,52)$ & 543 & $(1,57)$ \\
\hline & Disagree & 562 & $(9,09)$ & 535 & $(8,39)$ \\
\hline & $\begin{array}{l}\text { Strongly } \\
\text { disagree }\end{array}$ & a & (a) & a & (a) \\
\hline
\end{tabular}

a: The category does not apply in the country concerned, Data therefore missing

\section{Resource: PISA 2012 Database}

Graph 6 includes the percentage distribution of the responses to the item "Teachers take pride in this school." included in the PISA 2012 school questionnaire.

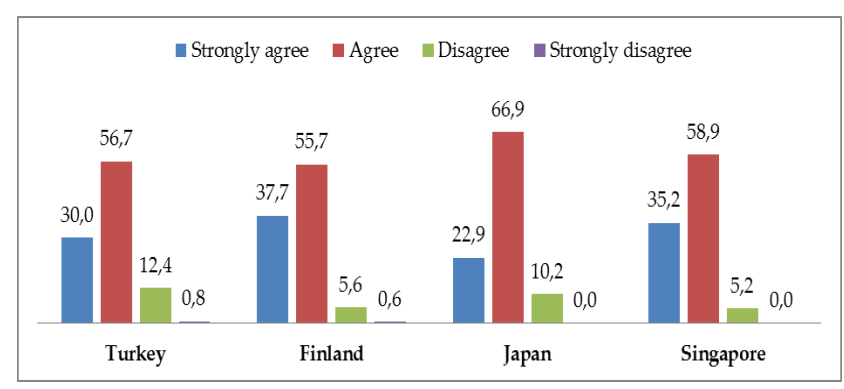

Graph 6. PISA 2012 "Teachers take pride in this school." 
As seen in Graph 6, the teachers take pride being at their schools according to the PISA data. This rate is around $90 \%$ in Turkey and Japan while it is more than $90 \%$ in other countries. An invincible result is that the maximum rate of the students in the schools whose principals disagree that "Teachers take pride in this school." belongs to Turkey (12.4\%).

Table 6 includes the achievement scores according to the responses to the item "Teachers take pride in this school." included in the PISA 2012 school questionnaire.

Table 6. Scores according to the responses to the item "Teachers take pride in this school."

\begin{tabular}{|c|c|c|c|c|c|}
\hline \multirow[b]{2}{*}{ Country } & \multirow[b]{2}{*}{ Category } & \multicolumn{2}{|c|}{ Mathematics } & \multicolumn{2}{|c|}{ Science } \\
\hline & & Mean & (SE) & Mean & (SE) \\
\hline \multirow{4}{*}{ Turkey } & Strongly agree & 487 & $(11,13)$ & 494 & $(8,60)$ \\
\hline & Agree & 436 & $(5,07)$ & 454 & $(4,25)$ \\
\hline & Disagree & 403 & $(9,99)$ & 424 & $(8,17)$ \\
\hline & Strongly disagree & 556 & $(14,81)$ & 572 & $(14,62)$ \\
\hline \multirow{4}{*}{ Finland } & Strongly agree & 522 & $(3,17)$ & 550 & $(2,79)$ \\
\hline & Agree & 516 & $(2,82)$ & 542 & $(3,11)$ \\
\hline & Disagree & 514 & $(7,35)$ & 541 & $(8,52)$ \\
\hline & Strongly disagree & 517 & $(3,74)$ & 548 & $(2,14)$ \\
\hline \multirow{4}{*}{ Japan } & Strongly agree & 571 & $(11,18)$ & 577 & $(9,71)$ \\
\hline & Agree & 533 & $(4,80)$ & 544 & $(4,57)$ \\
\hline & Disagree & 481 & $(11,89)$ & 497 & $(13,48)$ \\
\hline & Strongly disagree & $\mathrm{a}$ & (a) & $\mathrm{a}$ & (a) \\
\hline \multirow{4}{*}{ Singapore } & Strongly agree & 602 & $(2,75)$ & 580 & $(2,96)$ \\
\hline & Agree & 564 & $(1,65)$ & 541 & $(1,80)$ \\
\hline & Disagree & 512 & $(4,96)$ & 488 & $(4,70)$ \\
\hline & Strongly disagree & $\mathrm{a}$ & (a ) & $\mathrm{a}$ & (a ) \\
\hline
\end{tabular}

a: The category does not apply in the country concerned, Data therefore missing

Resource: PISA 2012 Database

As seen in Table 6, high morale of teachers in their schools increases the academic achievement average scores of students according to the PISA 2012 results. The academic achievement average score of the students of the principals in Singapore who responded with "strongly agree" to the item "Teachers take pride in this school." is 90 points higher in mathematics and 92 points higher in sciences than the academic achievement average scores of the students of the principals who responded with "strongly disagree". The least increase was in Finland. The academic achievement average scores of the students in Finland are 8 points higher in mathematics and 9 points higher in sciences.

Graph 7 includes the percentage distribution of the responses to the item "Teachers value academic achievement." included in the PISA 2012 school questionnaire.

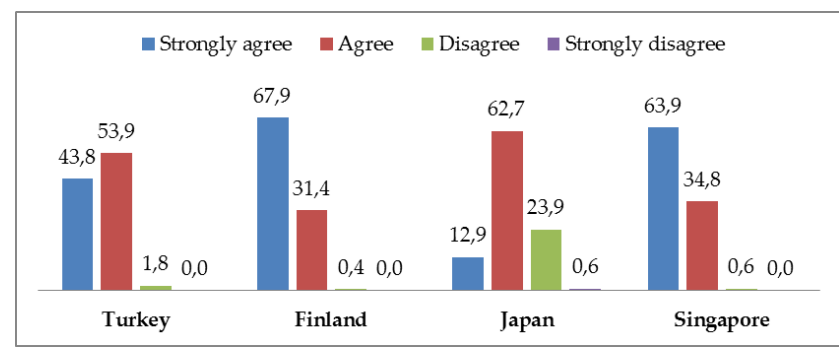

Graph 7. PISA 2012 "Teachers value academic achievement."

The order of the rates of countries is different for this item. Around $76 \%$ of the students in the schools in Japan whose principals strongly agree or agree that teachers value academic achievement, in other countries this rate is more than $95 \%$. In Turkey, about $97.7 \%$ of the principals strongly agreed or agreed that teachers value academic achievement (Graph 7).

Table 7 includes the achievement scores according to the responses to the item "Teachers value academic achievement." included in the PISA 2012 school questionnaire.

Table 7. Scores according to the responses to the item "Teachers value academic achievement."

\begin{tabular}{|c|c|c|c|c|c|}
\hline \multirow[b]{2}{*}{ Country } & \multirow[b]{2}{*}{ Category } & \multicolumn{2}{|c|}{ Mathematics } & \multicolumn{2}{|c|}{ Science } \\
\hline & & Mean & (SE) & Mean & (SE) \\
\hline \multirow{4}{*}{ Turkey } & Strongly agree & 473 & $(9,37)$ & 484 & $(7,70)$ \\
\hline & Agree & 431 & $(5,12)$ & 450 & $(4,39)$ \\
\hline & Disagree & 354 & $(16,43)$ & 387 & $(16,45)$ \\
\hline & Strongly disagree & $\mathrm{a}$ & (a) & $\mathrm{a}$ & (a) \\
\hline \multirow{4}{*}{ Finland } & Strongly agree & 520 & $(2,06)$ & 547 & $(2,20)$ \\
\hline & Agree & 515 & $(3,66)$ & 542 & $(4,13)$ \\
\hline & Disagree & $\mathrm{a}$ & (a) & $\mathrm{a}$ & (a) \\
\hline & Strongly disagree & a & (a) & $\mathrm{a}$ & (a) \\
\hline \multirow{4}{*}{ Japan } & Strongly agree & 583 & $(12,11)$ & 584 & $(10,90)$ \\
\hline & Agree & 548 & $(4,68)$ & 558 & $(4,53)$ \\
\hline & Disagree & 483 & $(7,10)$ & 499 & $(7,95)$ \\
\hline & Strongly disagree & 439 & $(4,60)$ & 463 & $(1,52)$ \\
\hline \multirow{4}{*}{ Singapore } & Strongly agree & 584 & $(1,80)$ & 560 & $(1,91)$ \\
\hline & Agree & 560 & $(2,27)$ & 539 & $(2,18)$ \\
\hline & Disagree & 489 & $(14,57)$ & 458 & $(14,10)$ \\
\hline & Strongly disagree & a & (a) & a & (a) \\
\hline
\end{tabular}

a: The category does not apply in the country concerned, Data therefore missing

Resource: PISA 2012 Database

As seen in Table 7, the value given by teachers to the academic achievement increases the achievement average scores of students according to the PISA 2012 results. The academic achievement average score of the students of the principals in Turkey who responded with "strongly agree" 
to the item "Teachers value academic achievement." is 119 points higher in mathematics and 97 points higher in sciences than the academic achievement average scores of the students of the principals who responded with "strongly disagree". The least increase was in Finland. The academic achievement average scores of the students in Finland are 5 points higher in mathematics and sciences.

Descriptive statistical results of the PISA 2012 data used in this study are located in Table 8 .

Table 8. Descriptive Statistics of the Index of Teacher Morale (TCMORALE)

\begin{tabular}{|c|c|c|c|c|}
\hline Country & Mean & Standard Deviation & Minimum & Maximum \\
\hline Singapore & -0.50 & 0.97 & -2.47 & 1.45 \\
\hline Japan & -0.49 & 0.95 & -2.47 & 1.45 \\
\hline Finland & 0.35 & 0.82 & -2.15 & 1.45 \\
\hline Turkey & -0.27 & 1.09 & -3.09 & 1.45 \\
\hline
\end{tabular}

HLM analysis was conducted to determine the effects of the index of Teacher Morale on achievement. Tables 9 and 10 show the variance decomposition for science and mathematics literacy.

Table 9. Variance Decomposition for Science Literacy

\begin{tabular}{|c|c|c|c|}
\hline PISA & $\begin{array}{c}\text { Students' Sciences } \\
\text { Achievement } \\
\text { Score Average }\end{array}$ & $\begin{array}{c}\text { Variance } \\
\text { within } \\
\text { schools (\%) }\end{array}$ & $\begin{array}{c}\text { Variance } \\
\text { between } \\
\text { schools (\%) }\end{array}$ \\
\hline Singapore & 546 & 64 & 36 \\
\hline Japan & 544 & 56 & 44 \\
\hline Finland & 527 & 88 & 12 \\
\hline Turkey & 454 & 42 & 58 \\
\hline
\end{tabular}

The variation at all levels is significant for science literacy. For science literacy, the maximum variance occurs between schools is in Turkey (58\%) and the minimum variance is in Finland (12\%). $88 \%$ of the science achievement scores of students in Finland is explained by the differences between students.

Table 10. Variance Decomposition for Mathematics Literacy

\begin{tabular}{|c|c|c|c|}
\hline PISA & $\begin{array}{c}\text { Students' Mathematics } \\
\text { Achievement Score } \\
\text { Average }\end{array}$ & $\begin{array}{c}\text { Variance } \\
\text { within } \\
\text { schools (\%) }\end{array}$ & $\begin{array}{c}\text { Variance } \\
\text { between } \\
\text { schools (\%) }\end{array}$ \\
\hline Singapore & 568 & 65 & 35 \\
\hline Japan & 534 & 46 & 54 \\
\hline Finland & 507 & 89 & 11 \\
\hline Turkey & 439 & 37 & 63 \\
\hline
\end{tabular}

The variation at all levels is also significant for mathematics literacy. For mathematics literacy, again the maximum variance occurs between schools is in Turkey $(63 \%)$ and the minimum variance is in Finland (11\%).

Graph 8 shows the effects of the index of Teacher Morale on academic achievement scores of the students participated in PISA 2012.

According to the HLM analysis results in Graph 8, it is seen that the index of teacher morale is significantly related with students' science achievement except Singapore. Particularly in Japan and Turkey, it is expected to play a role in the students' performance. The expected increase in the students' achievement scores in Turkey is about 20 points. Only, there is a negative effect on students' mathematics literacy scores in Finland, but it is not statistically significant.

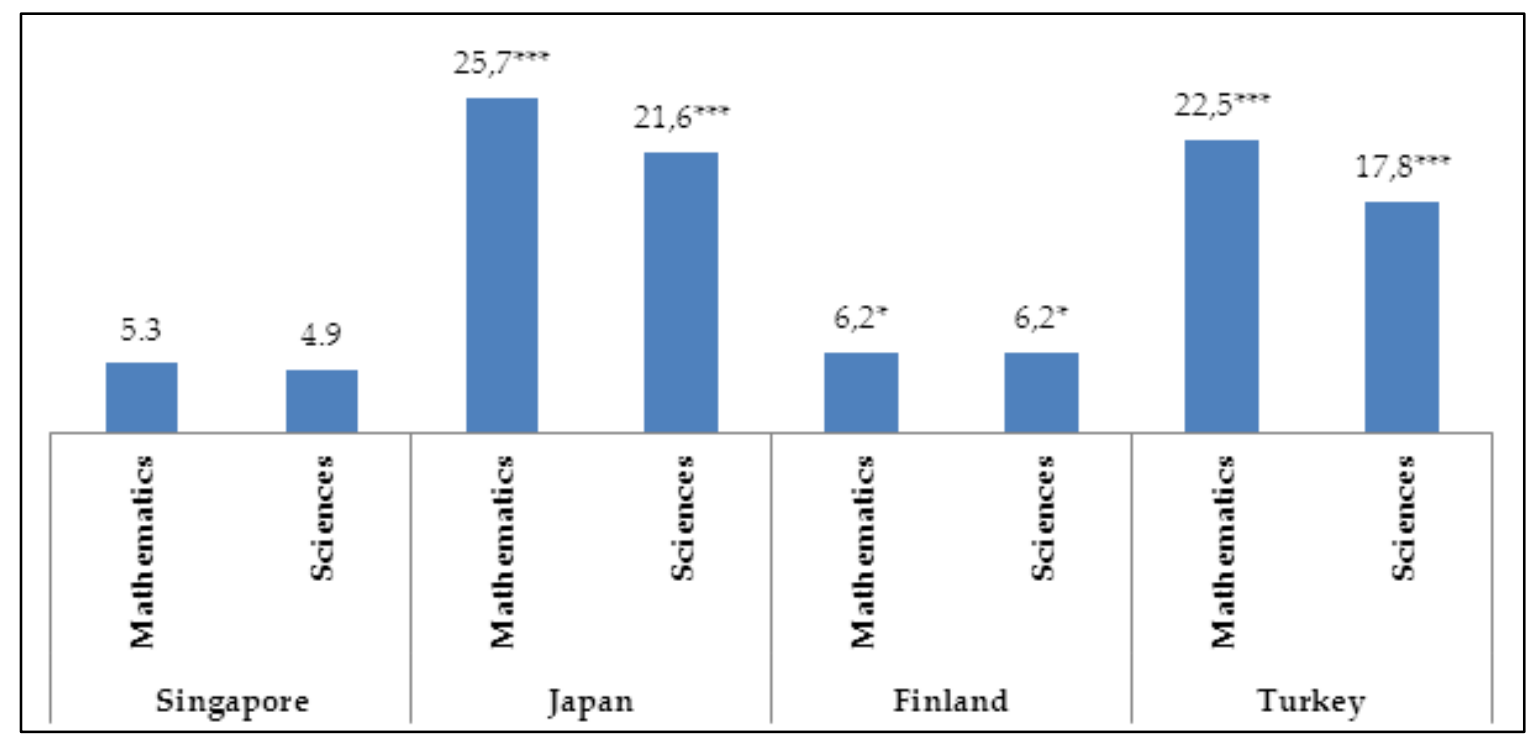

Note: ${ }^{*} \mathrm{p}<0.1 ; * * \mathrm{p}<0.01 ; * * * \mathrm{p}<0.001$

Graph 8. Fixed Effects Estimates for the Index of Teacher Morale. 


\section{Conclusions, Discussion and Recommendations}

In parallel with the literature, the present study demonstrated that the teacher morale and motivation generally has a significant role on students' science and math achievement in all countries. Although there are some differences between the results of TIMSS and PISA applications for some countries, it was found that the teacher morale and motivation generally has a positive effect according to both results. There are similar results in the literature. For example, Korur [12] studied the effects of the qualities of sciences teachers on the student achievement, attitude and motivation throughout Turkey and he found that the pedagogical content knowledge, lesson preparedness and personal traits/motivations of teachers were the variables with the highest effect on the physics achievement, attitude and motivation of the students.

When the results of TIMSS and PISA are considered together, it can be seen that the variance between teachers and schools change according to the age-groups. For example, for Japan it is found that the variance between teachers is $13 \%$ according to TIMSS 2011 results, where the variance between schools was found $44 \%$ according to PISA 2012 results. On the other hand, for Turkey, the variance between schools and teachers is always high according to both results. It is seen that the high performed countries are also the countries that can decrease the differences and inequalities between teachers and schools. According to the PISA and TIMSS results, the effect of teachers' motivation on the student achievement in Finland, which has one of the lowest differences of equal socio-economic opportunities, was found to be lower than the other countries. The study demonstrated that the teacher factor was more effective in countries with different income balance. For example in Turkey and Singapore, teacher motivation has more effect on the academic achievement of the students. This result also should be evaluated culturally. In Confucian Heritage Culture nations like Japan and Singapore, teachers are role models of correct behavior in society [14]. Teacher is more dominant in the classroom and there is not much emphasis on student participation. These cultural factors may also increase the effect of teacher characteristics on achievement.

One important result is that in high performer countries principals express a high morale and motivation for their teachers. For example, in the countries except Turkey, more than $90 \%$ of the students in the schools whose principals strongly agree or agree that teachers have high morale rate, where this rate is less than $90 \%$ in Turkey. Also, less than $90 \%$ of the students in the schools in Turkey whose principals strongly agree or agree that teachers work with enthusiasm, in other countries this rate is more than $90 \%$.

Another important point of teacher motivation is its effect on students' motivation. The researchers asserted that teacher morale has a key role on students' motivation.
Similarly, Ersoy [7] stated that the student motivation varied according to the school, environment and socio-economic environment of the student and thus the motivation was another element affecting the academic achievement and problem solving skill of the student. They emphasized that high morale level of the teachers in the school affects the school environment and there causes some changes in the academic achievement of students.

It is seen that the job satisfaction and motivations of teachers vary between countries. Similar results were also emphasized in the findings from Teaching and Learning International Survey (TALIS) [17]; job satisfaction varies little at the country level. According to the results of this study; since high teacher morale is more likely to affect positively the academic achievements of students, educators and politicians are recommended to conduct works to increase the teacher morale and motivation. For this purpose, increasing teachers' salary is well known strategy emphasized in the studies [9, 10]. Moreover, it may affect the appreciation of the teaching profession by the society and high status of the profession may provide an effective motivation for teachers. Material support, incentives, providing good physical conditions are some of the duties of governments. But, these are not enough for raising teacher morale and motivation. Considering the highest teacher morale statistics in Finland, governments should also show the importance they give to the teaching profession. The governments should provide a fair system for employing student teachers and increasing teacher qualifications. Briefly governments should show their trust to teachers.

Although, high teacher motivation in countries generally has positive effect on the academic achievement of the students, commonly, it is found that teachers show low degree of motivation [11]. Thus, the researches should focus more on the teacher motivation. The researchers also recommend more longitudinal works to determine the effect of the teacher motivation and other teacher qualities on the academic achievement of students.

\section{Acknowledgements}

We are very grateful to experts for their appropriate and constructive suggestions to improve this template.

\section{REFERENCES}

[1] Akyüz, G. (2006). Türkiye ve Avrupa Birliği Ülkelerinde Öğretmen ve Sınıf Niteliklerinin Matematik Başarısına Etkisinin İncelenmesi. İlköğretim On-Line Dergisi, 5(2), 75-86, [Online] http://ilkogretim-online.org.tr adresinden 04 Ağustos 2013 tarihinde indirilmiştir.

[2] Aztekin, S. ve Y1lmaz, H.B. (2014).The effects of human and material resources on students' math achievement in 45 countries. Problems of Education in the 21 st Century. 
Volume 62, ISSN 1822-7864.

[3] Balcı, E. (1991). Öğretmenin Sosyal Statüsü ve Ödüllendirilmesi. Hacettepe Üniversitesi Eğitim Fakültesi Dergisi, Say1 6 [1991] 121-128.

[4] Bennell, P.S. and K. Acheampong. 2003. Research project application to DFID: Teacher motivation and incentives in low-income developing countries. Knowledge and Skills for Development, Brighton.

[5] Cemaloğlu, N, ve Erdemoğlu, Ş.D. (2007). Öğretmenlerin Mesleki Tükenmişlik Düzeylerinin Farklı Değişkenlere Göre İncelenmesi, Kastamonu Eğitim Dergisi, 15(2) 465-484 Kastamonu 2007.

[6] Ellenberg, F. C. "Factors Affecting Teacher Morale.” NASSP Bulletin 56, 12 (December 1972): 76.

[7] Ersoy, E. ve Başer, N. (2010). "Probleme Dayalı Öğrenme Sürecinin Öğrenci Motivasyonuna Etkisi." Turkish Studies International Periodical For the Languages, Literature and History of Turkish or Turkic Volume 5/4 Fall. p. 336-357. 2010. Ankara-Turkey.

[8] Esteve, J. M. (2000). The transformation of the teachers' role at the end of the twentieth century: new challenges for the future. Educational Review, 52(2), pp. 197-207. EJ 609284.

[9] Fraser, H., Draper, J. \& Taylor, W. (1998). The Quality of Teachers' Professional Lives: Teachers and Job Satisfaction. Evaluation \& Research In Education. Vol. 12, Iss. 2.

[10] Fuming, X. \& Jiliang, S. (2007). Research on Job Satisfaction of Elementary and High School Teachers and Strategies to Increase Job Satisfaction. Chinese Education \& Society Vol. 40 , Iss. 5

[11] Jesus, S.N. \& Lens, W. (2005). An Integrated Model for the Study of Teacher Motivation. Applied Psychology: An International Review, 54 (1), 119-134

[12] Korur, F. (2001). The Effects of Teachers Characteristics on High School Students' Physics Achievement, Motivation and Attitudes. Unpublished master thesis, Middle East Technical University, Graduate School of Natural and Applied Sciences, Ankara.

[13] Miller, William C. (1981). "Staff Morale, School Climate, and Education Productivity. Educational Leadership 38, 6 (March 1981): 483-86. EJ 243839.

[14] Nguyen, P-M., Terlouw, C. \& Pilot, A. (2006). Culturally appropriate pedagogy: the case of group learning in a Confucian Heritage Culture context. Intercultural Education,
Vol. 17, No. 1, March, pp. 1-19

[15] Nye, B., Spyros, K. and Larry, H. (2004). How Large Are Teacher Effects? Educational Evaluation and Policy Analysis 26: $237-57$.

[16] OECD (2012), PISA 2012 Assessment Framework: Key competencies in Reading, Mathematics and Science, OECD, Paris.

[17] OECD. (2009). Creating Effective Teaching and Learning Environments: First Results from TALIS - ISBN 978-92-64-05605-3

[18] Organization for Economic Co-operation and Development (OECD). (2013). PISA 2012 Results: What Makes Schools Successful? Resources, Policies and Practices, IV, PISA, OECD Publishing http://dx.doi.org/10.1787/9789264201156-en

[19] Organization for Economic Co-operation and Development, (OECD). (2012). PISA 2012 Assessment Framework: Key competencies in Reading, Mathematics and Science. OECD Publishing, Paris, 2012.

[20] Özler D. (1998). “Temel Eğitimde (İlköğretim) Öğretmen Niteliklerinin Öğrenci Başarılarına Etkileri Üzerine Bir İnceleme. "Yayımlanmamış yükseklisans tezi, Dokuz Eylül Üniversitesi, Eğitim Bilimleri Enstitüsü, İzmir.

[21] PISA Data Base: https://www.oecd.org/pisa/pisaproducts/pis a2012database-downloadabledata.htm

[22] Raudenbush, S.W., Bryk, A.S. and Congdon, R. (2004). Hierarchical Linear and Nonlinear Modeling: HLM for Windows (Version 6.00) [Computer Software]. Lincolnwood, IL: Scientific Software International.

[23] Rivkin, S., Eric H. and John K. (2005).Teachers, Schools, and Academic Achievement. Econometrica 73: 417-58.

[24] TIMSS 2011 Assessment Frameworks: http://files.eric.ed.gov/fulltext/ED512411.pdf

[25] Türk Dil Kurumu (TDK), (2016). Türk Dil Kurumu Büyük Türkçe Sözlük.

[26] Wayne, A. J. and Youngs, P. (2003). Teacher Characteristics and Student Achievement Gains: A Review. Review of Educational Research, 73(1), 89-122.

[27] Woltman, H., Feldstain, A., MacKay, J. C. and Rocchi, M. (2012). "An introduction to hierarchical linear modeling" Tutorials in Quantitative Methods for Psychology 2012, Vol. 8(1), p. 52-69. 